\title{
INFORMATION SUPPORT FOR RW MANAGEMENT WITHIN THE FRAMEWORK OF THE FEDERAL TARGET PROGRAM NUCLEAR AND RADIATION SAFETY 2
}

\author{
Ginevec E. V. ${ }^{1}$, Tihonova A. A. ${ }^{1}$, Dorofeev A. N. ${ }^{1}$, Ivanov A. Yu. ${ }^{2}$, Aleksandrova T. A. ${ }^{2}$, Drozdov V. V. ${ }^{2}$ \\ ${ }^{1}$ State Corporation “Rosatom”, Moscow, Russia \\ ${ }^{2}$ Nuclear Safety Institute of RAS, Moscow, Russia
}

Article received on July 23, 2019

\begin{abstract}
The paper provides a detailed overview of current opportunities and perspective tasks associated with information support of radioactive waste management, including references to the digital economy with an emphasis on radioactive waste disposal.
\end{abstract}

Key words: radioactive waste (RW), radioactive waste disposal, disposal facility, information support, federal target program.

\section{Introduction}

At present time, efforts scheduled under the federal target program "Nuclear and Radiation Safety in 2016-2030" (FTP NRS-2) are being actively implemented providing for the establishment of all necessary elements corresponding to the national system for SNF and RW management with the required rates maintained in terms of accumulated SNF reprocessing and RW disposal [1]. Regular analysis of the practice associated with RW transfer for disposal seems to be essential as conditioning and disposal of the accumulated RW is considered as a key focus area under the federal target program NRS-2 enabling to develop relevant proposals on how its efficiency can be increased. The need for such an analysis was also driven by the fact that with the start of relevant activities on accumulated RW transfer, some points of concern have been identified being associated with the practical implementation of the activities in 2016-2018 [2].

Practical experience gained allowed us to perceive the potential of the state management body responsible for RW management in assessing waste amounts and quality of relevant activities performed. This article attempts to provide a more detailed picture of today's potential and promising tasks in this area also accounting for the perspectives of implementing the digital economy with particular emphasis placed on RW disposal.

\section{Information and analytical support of RW management activities}

Three key focus areas should be identified within the information and analytical support activities addressing the management of accumulated RW under the federal target program NRS-2:

- supporting organizations during the execution of relevant contracts and development of reporting materials on FTP implementation;

- information and analytical support of activities performed by regulating and supervisory bodies; 
- information and analytical support of the state management body responsible for RW management enabling the decision making to achieve higher quality and efficiency indicators.

Efforts associated with records collection, systematization and upgrading were implemented under the information and analytical support activities for monitoring the effectiveness and management of measures performed under FTP NRS-1 and FTP NRS-2. The records involved, in particular, soft and hard copies of government contracts, agreements and reporting materials on completed and planned operations. Since 2008, more than 7 thousand documents from 78 contractors dealing with the implementation of certain activities covered by these FTPs were processed. The volume of collected and systematized soft copies of the documents amounted to over $135 \mathrm{~GB}$.

Access to the electronic archive allows grouping and selecting data and reporting materials by various categories and their possible combinations, such as: contractor, facility, concerned focus area (including radioactive waste management), cost, deadlines, key words and etc. Quick access to a large array of reporting materials presented in an electronic form including contextual search tools is seen as the main advantage of such a systematized electronic archive.

During the development of documents and reporting materials done at the request of regulating and supervisory authorities, of key importance is the completeness of the requested information and relevant timelines for its presentation. Over the past three years of FTP NRS-2 implementation, requests were processed primarily by the Accounts Chamber of the Russian Federation, the Federal Treasury and the Federal Service for Intellectual Activity (ROSPATENT), concerning: the status of the Program at a specific point in time, information on the results achieved, including those subject to legal protection, and the used financial resources. Responses to the requests requiring some analytical processing of primary data on the implementation of FTP NRS-2 activities are compiled using modern information processing tools in the shortest possible time. Usually this process takes 1-2 days. Basically, processing and generation of responses to simple or common inquiries takes no more than several hours.

The management body in the field of RW management is responsible for upgrading the efficiency of RW disposal activities with several areas being involved, including organizational, methodological and analytical ones.

In terms of organizational aspects, consistent evaluations of financial liabilities and possible deadlines associated with nuclear legacy cleanup efforts covering the entire nuclear industry, including disposal of accumulated RW and management of non-retrievable RW are performed. This focus area also involves the development of a regulatory framework aimed at centralizing the management and funding of nuclear legacy cleanup activities with the possibility of establishing a single responsible organization - National Operator for Nuclear Legacy Decommissioning. To refine the tools aimed at increasing the efficiency of nuclear legacy decommissioning accounting for a potential of their transfer to a single organization (National Operator for Decommissioning), relevant pilot sites have been already identified (selected).

Cost standards are currently being developed for the implementation of standard operations (technological conversion) taking into account waste characteristics (type, total and specific activity, density, etc.) to increase the efficiency of RW management operations and their planning (including disposal). To collect and evaluate the data on the management costs for certain RW types, it's now discussed if the establishment of some additional requirements in the terms of references of state contracts involving waste management operations is feasible. To obtain more accurate estimates concerning the effectiveness of RW disposal, it seems reasonable to establish the following requirement: a stage specified under the state contract (agreement) shall correspond to one stage of a technological process (conversion) of RW management prior to waste transfer for disposal (retrieval, packaging, RW transportation to the site where the waste is conditioned to comply with waste acceptance criteria for disposal, etc.).

Evaluation of efforts implemented under the case study of accumulated RW transfer for disposal

This article focuses on evaluating the effectiveness of activities performed based on the example of RW disposal. The following characteristics are seen as the key ones in the evaluation of pre-disposal RW management activities:

- containers filling based on such indicators as weight and activity, including total and specific activity for individual dose-contributing radionuclides;

- compliance of the data on radiation characteristics presented in the waste certificates (passports) with actual characteristics of packages filled with waste.

The above characteristics were presented in [3] giving an idea of packaging effectiveness and allowing to say if the container was chosen correctly, 
including based on the period of potential hazard presented by the package with RW.

The decision making regarding these factors is also driven by the following reasons: by evaluating the normality of mass and density distribution in the waste, one can assess the quality of packaging and filled in waste package certificates (passports) given the same morphological composition of the RW and the available data on the actual mass of the waste in the primary packaging. Thus, with the calculated small standard deviation one can state that the practice used for waste package formation can be deemed successful.

Analysis of RW radionuclide composition, as well as changes in its activity over time, allows us to assess the disposal feasibility for a batch of waste being under consideration at the moment. This factor should be taken into account, in particular, due to the need of identifying the economic component of RW disposal.

At this stage, it's considered advisable to focus on the waste managed by Rosenergoatom Concern, since at present time this waste makes up the biggest part of the accumulated waste inventory transferred for disposal $\sim 15$ thousand $\mathrm{m}^{3}$. Moreover, the Concern is seen as a biggest RW generator, thus, allowing to extend the recommendations provided on the management of newly generated waste. To assess the effectiveness of the current practice considering accumulated RW transfer to disposal sites, RW shipped from Leningrad and Balakovo NPPs were studied at the first place (Table 1).

\section{Table 1. Morphological composition of RW transferred} for disposal

\begin{tabular}{|c|c|c|}
\hline Enterprise & $\begin{array}{l}\text { Executing } \\
\text { organization }\end{array}$ & $\begin{array}{l}\text { Morphology } \\
\text { of the waste }\end{array}$ \\
\hline Leningrad NPP & FSUE Radon & Construction waste \\
\hline Balakovo NPP & FSUE Radon & Salt melt \\
\hline
\end{tabular}

At the first stage, the certificates for RW packages delivered from Balakovo NPP were checked to assess the quality of their filling. According to the data presented, the waste transferred by FSUE "NO RAO" is a salt melt with its activity level corresponding to RW class 3 based on RW classification system for disposal purposes. The transferred waste was packaged into $0.2 \mathrm{~m}^{3}$ metal drums, installed into NZK type containers (4 drums in each container) with the voids grouted with cement mortar. Statistical analysis of waste mass and density distribution over the packages, presented in Figures 1 and 2 , showed normal distribution of these values in the batch under consideration. Since the density was calculated based on the volume of the primary

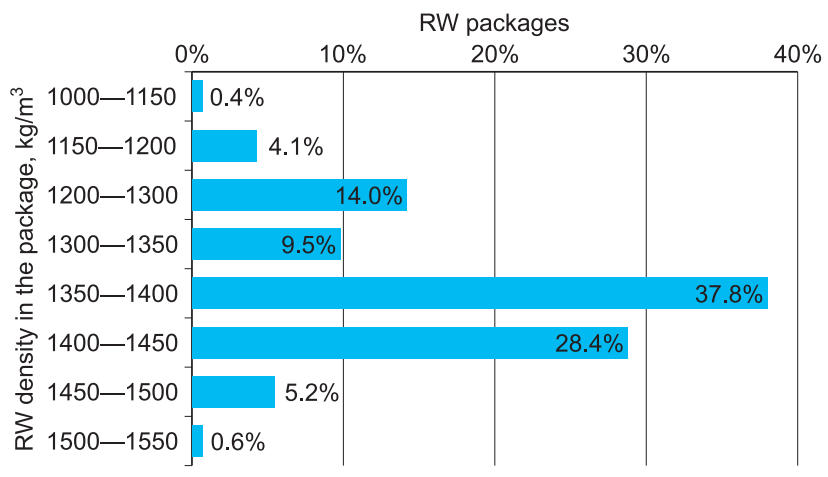

Figure 1. Density distribution for RW packages

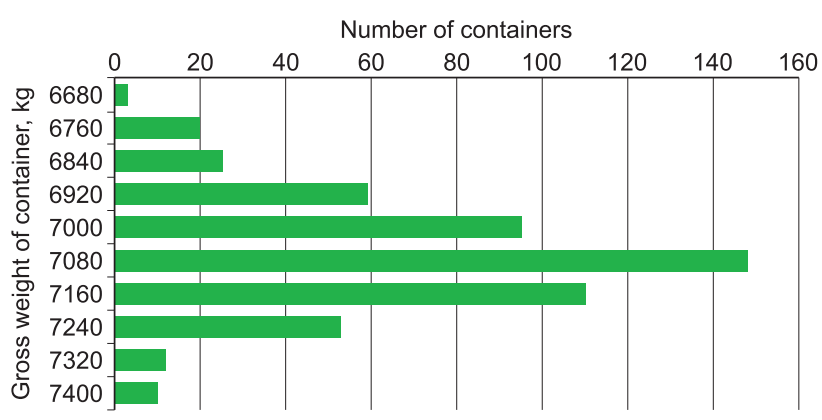

Figure 2. Distribution of $R W$ mass in $R W$ packages

waste packaging indicated in the certificates, the variability of densities in the RW batch can be explained by both incomplete filling of the primary packaging with waste and possible corrosion of the primary packaging (metal drums) and subsequent leakage of salt melt during their storage at the NPP site. Such a variation in packaging mass can be explained by the following:

1.Differences in the filling extent of the voids between the primary packages in the container grouted with cement;

2. Variations of mass NZK characteristics;

3. Variations of mass characteristics for a filled primary package.

Calculations of dose rates on the package surface carried out using the TDMCC software tool also showed that the calculated data corresponded to the values indicated in relevant RW certificates.

The above assessment of the characteristics indicated in the RW package certificates revealed no big errors made in the certificates filled in for RW class 3 (salt melt) from Balakovo NPP.

According to data presented in the certificates, short-lived beta-emitting radionuclides with a halflife of less than 31 years were considered as major dose contributing radionuclides in the considered batches of waste. Specific activity of the RW batch was also assessed (Figure 3) showing that relevant values were two orders of magnitude lower than the upper limit specified for RW class 3 with a shift in 


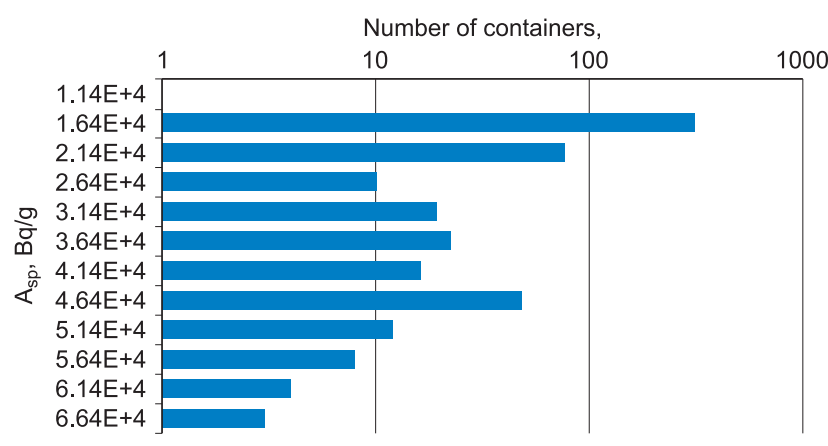

Figure 3. Distribution of RW specific activity in packages

the specific activity to lower values being revealed as well.

At present time, 4 WWER-1000 power units are being operated at Balakovo NPP. Operation of SRW storage facilities is expected to be stopped simultaneously with the final shutdown of the NPP units the final shut down of the last unit is scheduled for 2053. If the most promising (based on decommissioning costs) decommissioning concept is chosen "immediate dismantling", the dismantlement of SRW storage facilities with accumulated waste held therein is scheduled to start no earlier than 5 years after the NPP final shutdown. Since we are talking about short-lived RW and given the facts mentioned above, option suggesting RW storage at the NPP site until the start of decommissioning can be considered: variations of RW disposal costs should be evaluated accounting for different timing for waste hand over to FSUE "NO RAO" for disposal. To perform such assessments, one should estimate the age of the packages. The certificates provide no information on the date of primary package formation, therefore, the "age" of the waste transferred for disposal should be estimated based on the ratio of current and initial (at the time of the package formation) activities of ${ }^{134} \mathrm{Cs}$ and ${ }^{137} \mathrm{Cs}$. The ratio between ${ }^{137} \mathrm{Cs}$ and ${ }^{134} \mathrm{Cs}$ activities was taken as the initial one according to the data presented in [4]. Figure 4 shows the results of this analysis evidencing that in 2018 the age of over $65 \%$ of the RW transferred to FSUE NO RAO for disposal amounted to $7-10$ years.

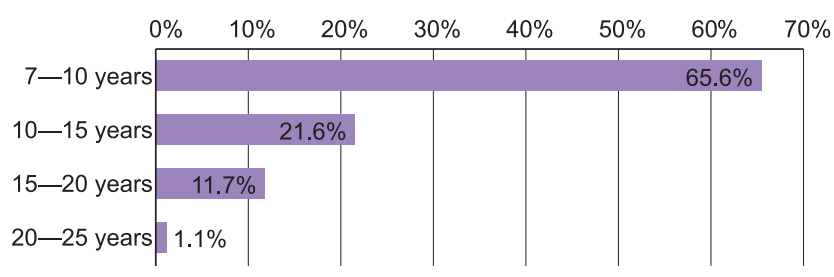

Figure 4. Age of RW from Balakovo NPP for the packages considered
Based on the activity of RW packages indicated in the certificates, as well as the performed "age" estimates for the accumulated RW, one can state that until the NPP and SRW storage facility shutdown, more than $75 \%$ of the RW currently categorized as RW class 3 [5] will be recategorized as RW class 4 (Figure 5).

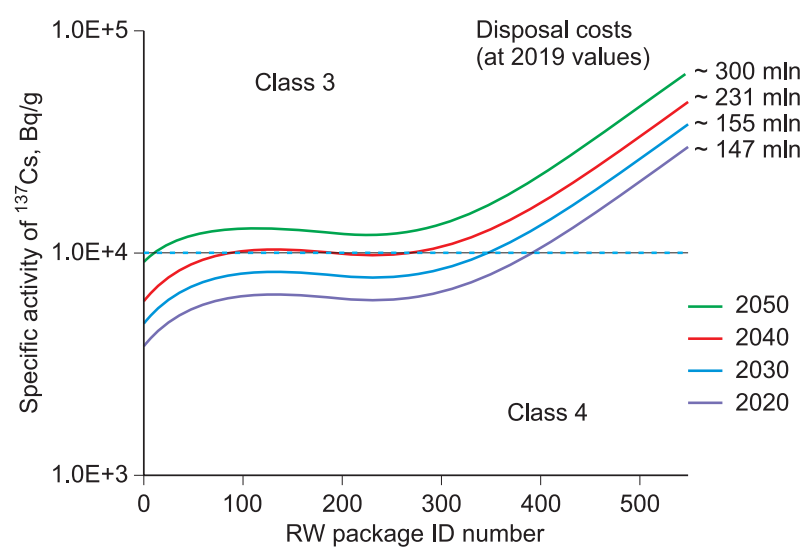

Figure 5. Changes in RW class depending on the storage time

According to current tariffs set for RW class 3 [6], disposal of 540 NZK-type packages with a total volume of 2,000 $\mathrm{m}^{3}$ would cost more than 350 million rubles (VAT). The disposal costs for RW class 3 and 4 may differ by more than 3 times. Thus, based on the example of an RW batch already transferred to FSUE "NO RAO", one can conclude that an increase in the waste storage time will significantly reduce the cost of its disposal due to a drop down in RW class (Figure 6).

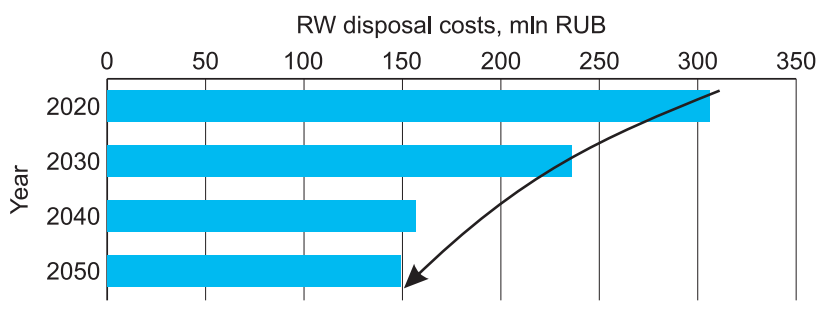

Figure 6. Variations of disposal costs for Balakovo NPP RW depending on the storage time (till 2050 not accounting for the cost of RW storage at NPP)

If the waste, the activity of which is associated with short-lived ${ }^{137} \mathrm{Cs}$, is subject to a long-term cooling in temporary storage facilities, a quite rapid decrease in its activity is observed due to natural decay processes.

Thus, for example, some waste accumulated at Leningrad NPP was transferred to FSUE "NO RAO" for disposal. The waste was categorized as VLLW. Waste certificates were analyzed. It was found that 
after 30 years of storage more than $80 \%$ of the transferred waste will no longer be categorized as radioactive (Figure 7). Similar analysis of VLLW certificates belonging to other organizations, for example, Atomflot, revealed the same situation.

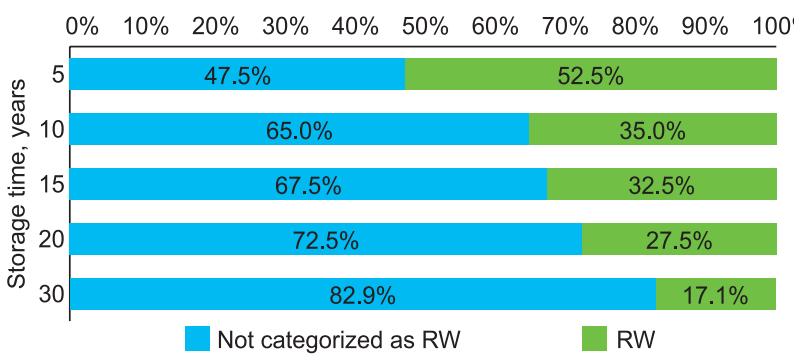

Figure 7. Dynamics showing the changes in RW categories for waste from FSUE Atomflot and Leningrad NPP

Disposal of such radioactive waste seems to be not feasible at all from a financial perspective. The practice shows, that construction of RWDF and its commissioning is a lengthy process. Therefore, already operating RWDF designed to accommodate RW class 3 and 4 should not be filled with waste the potential hazard period of which is much shorter than the design life of the engineered safety barriers. Otherwise this situation can result in a shortage of available RWDF capacities for the waste actually requiring disposal. Thus, allocation of a separate RW category for VLLW in the waste classification system and construction of a purpose designed facility for VLLW disposal (taking into account the time needed for design development, licensing and construction) can be considered as a promising option in case of delayed short-lived RW disposal. Purpose designed VLLW disposal facilities have been constructed abroad, and this practice showed that in most cases this type of RWDF can be constructed at already available nuclear sites [7].

Therefore, to build an economically sound RW management flow chart, a model should be developed to calculate the costs of such RW management before its hand over to the national operator. Such a model would help to develop proposals on how to reduce the financial costs payed by enterprises taking into account relevant drop down in RW class.

Thus, as the amount of operations associated with the transfer of accumulated RW for disposal grows, it is not only that the high cost of this procedure becomes evident, but it also demonstrates the premature start of such waste transfer to disposal sites. To reduce the costs and inefficient use of RWDF capacities, especially of those designed for RW class 3 disposal, plans for RW disposal operations and their implementation should be optimized. Optimization of disposal costs and the efficiency of RW management activities is seen as the key task in this area, as well as the rational use of RWDF capacities, including the optimization areas discussed in [8] when dealing with short-lived LLW and VLLW.

\section{Conclusion}

Efforts implemented to date have been analyzed allowing to identify several points that should not be considered critical for now. However, relevant decisions are to be reviewed in the future. First of all, decision dealing with the current management of short-lived VLLW seems to be questionable. Despite the fact that at present time such waste is categorized as retrievable RW class 4, its further disposal in RWDF designed for RW class 3 and 4 will lead to irrational use of available disposal capacities. The drop down in the waste class for most part of RW class 3 during the first 30 years identified in the current study, reveals the flaws of existing RW classification system for disposal purposes. An alternate RW management scenario may provide for temporary storage of LLW and ILW to decrease its specific activity allowing to categorize the waste as non-radioactive or to assign the waste to a lower RW category.

The in-depth study of RW package formation clearly revealed the opportunities allowing to increase the work efficiency with many ways enabling to seize them. Firstly, stimulating requirements may be set forth to build the work flows for the management of accumulated RW in a more efficient way [3]. Secondly, the contractors could be provided with digital tools. Such digital tools would provide them with real time data on the effectiveness of RW package formation. Thirdly, specialists of the management authority may be provided with such tools as well.

The best-case scenario suggests that the latter two methods can be implemented under USS RW. In this case, the accounting system can be transformed into a digital tool supporting the adoption of technical decisions. Such a system will enable to evaluate the quality of the formed RW packages in a prompt manner (either immediately after the access to the data presented in RW certificate is provided or before, when forecast values are specified) showing whether relevant results are good or satisfactory. If RW package formation is considered unsatisfactory, a warning may be provided indicating the possible outcomes that may arise when the package is handed over to the national operator, including non-admission of the package due to its non-compliance with RW classification criteria, waste acceptance criteria for disposal, etc. 
Ultimately, the case studies involving an indepth analysis considered above should turn into standard procedures under an end-to-end quality assurance system covering the operating organizations, specialized organizations, RW disposal operator and the customers.

\section{References}

1. Federalnaya tselevaya programma «Obespechenie yadernoy $\mathrm{i}$ radiatsionnoy bezopasnosti na 2016-2020 godyi i na period do 2030 goda» [The Federal target program «Ensuring nuclear and radiation safety for 2016-2020 and for the period up to 2030»]. URL: https://фцп-ярб2030.pф/.

2. Abramov A. A., Dorofeev A. N., Deryabin S. A. Razvitie EGS RAO v ramkah rabot po federalnoy tselevoy programme obespecheniya yadernoy i radiatsionnoy bezopasnosti [Development of USS RW in the Framework of Federal Targeted Program of Nuclear and Radiation Safety Assurance]. Radioaktivnye othody $-R a-$ dioactive Waste, 2019, no. 1 (6), pp. 8-24. (In Russian). 3. Abalkina I. L., Linge I. I. Osobennosti obrascheniya s RAO ot vyivoda iz ekspluatatsii [Peculiarities of Decommissioning Waste Management]. Radioaktivnye othody Radioactive Waste, 2018, no. 3 (4), pp. 6-15. (In Russian). 4. Kolobashkin V. M., Rubtsov P. M., Ruzhanskiy P. A., Sidorenko V. D. Radiatsionnyie harakteristiki obluchennogo yadernogo topliva: Spravochnik [Radiation characteristics of spent nuclear fuel]. Manual, Moscow, Energoatomizdat Publ., 1983. 382 p.
5. Postanovleniye Pravitel'stva Rossiyskoy Federatsii ot 19 oktyabrya 2012 g. № 1069 «O kriteriyakh otneseniya tverdykh, zhidkikh i gazoobraznykh otkhodov k radioaktivnym otkhodam, kriteriyakh otneseniya radioaktivnykh otkhodov $\mathrm{k}$ osobym radioaktivnym otkhodam i k udalyayemym radioaktivnym otkhodam i kriteriyakh klassifikatsii udalyayemykh radioaktivnykh otkhodov» [Decree of the Government of the Russian Federation of 19 October 2012 No.1069 "On the criteria of designation of solid, liquidand gaseous waste as radioactive waste, criteria of radioactive waste designation as non-retrievable radioactive waste and retrievable radioactive waste and criteria of classification of removable radioactive waste"].

6. Tarify na zahoronenie radioaktivnyih othodov na period s 2018 po 2022 godyi [Radioactive waste disposal tariffs for the period from 2018 to 2022]. URL: http://www.norao.ru/about/tarify/.

7. Abalkina I. L. Opyt zahoroneniya ONAO: perspektivy dlya Rossii [VLLW Disposal Experience: Perspectives for Russia]. Radioaktivnye othody - Radioactive Waste, 2018, no. 4 (5), pp. 15-23. (In Russian). 8. Vedernikova M.V., Linge I.I., Samoylov A.A., Ivanov A. Yu. Optimizatsiya obrascheniya s zagryaznennyimi materialami i RAO v predelah promyishlennyih ploschadok [Optimization of contaminated materials and radioactive waste management within industrial sites]. Radioaktivnye othody $-R a-$ dioactive Waste, 2019, no. 2(7), pp. 6-17. (In Russian). DOI: 10.25283/2587-9707-2019-2-6-17

\section{Information about the authors}

Ginevets Elena Vladimirovna, Manager of the Project Office, State Corporation Rosatom (24, Bolshaya Ordynka St, Moscow, 119017, Russia), e-mail: EVGinevets@rosatom.ru.

Tikhonova Alena Aleksandrovna, Head of the Project Office, State Corporation Rosatom (24, Bolshaya Ordynka St , Moscow, 119017, Russia), e-mail: AATikhonova@rosatom.ru.

Dorofeev Aleksandr Nikolaevich, PhD, Head of the Project Office, State Corporation Rosatom (24, Bolshaya Ordynka St., Moscow, 119017, Russia), e-mail: ANDorofeev@rosatom.ru.

Ivanov Artem Yurievich, Head of Department, Nuclear Safety Institute of RAS (52, Bolshaya Tulskaya st., Moscow, 115191, Russia), e-mail: aivanov@ibrae.ac.ru.

Aleksandrova Tatiana Aleksandrovna, Engineer, Nuclear Safety Institute of RAS (52, Bolshaya Tulskaya st., Moscow, 115191, Russia), e-mail: aleksandrova_ta@ibrae.ac.ru.

Drozdov Vitaliy Vladimirovich, Head of the Group, Nuclear Safety Institute of RAS (52, Bolshaya Tulskaya st., Moscow, 115191, Russia), e-mail:drozdov@ibrae.ac.ru

\section{Bibliographic description}

Ginevec E. V., Tihonova A. A., Dorofeev A. N., Ivanov A. Yu., Aleksandrova T. A., Drozdov V. V. Information Support for RW Management within the Framework of the Federal Target Program Nuclear and Radiation Safety 2. Radioactive Waste, 2019, no. 3 (8), pp. 28-35. DOI: 10.25283/2587-9707-2019-3-28-35. (In Russian). 